\title{
STUDI LITERATUR PENGARUH PEMBERIAN BEBERAPA ZAT TERHADAP PERUBAHAN STRUKTUR HEPAR TIKUS PUTIH (Rattus norvegicus) DAN MENCIT (Mus musculus)
}

\author{
Nurfausiah Fitriani', Maghfirotur Rif'ah ${ }^{2}$, Rahmi Aulia ${ }^{3}$, Saifullah Hidayat ${ }^{4}$ \\ ${ }^{1,2,3,4}$ Program Studi Pendidikan Biologi UIN Walisongo Semarang J1. \\ Walisongo No.3-5, Tambakaji, Semarang \\ e-mail: ${ }^{1}$ 1908086014_fitriani@ student.walisongo.ac.id, ${ }^{2}$ \\ maghfirotur_1908086028@student.walisongo.ac.id, \\ ${ }^{3}$ rahmiaulia_1908086011@ @student.walisongo.ac.id, ${ }^{4}$ hidayatsaifullah@walisongo.ac.id
}

\begin{abstract}
ABSTRAK
Hepar merupakan bagian organ yang memiliki fungsi yang sangat berguna bagi tubuh yang mana hepar berfungsi untuk menetralkan racun.Penyebab kerusakan sel-sel hepar antara lain oleh obat, virus dan berbagai macam senyawa lainnya yang mengandung hepatotoksik. Akan tetapi beberapa zat atau ekstrak mempunyai daya yang bisa menyembuhkan kerusakan sel hepar. Penelitian ini bertujuan untuk mengidentifikasi pengaruh pemberian beberapa zat terhadap perubahan struktur hepar tikus putih dan mencit. Metode penelitian menggunakan jenis penelitian studi pustaka yaitu kegiatan melakukan penelitian dengan cara membaca serta mempelajari literatur yang ada hubungannya dengan objek penelitian. Dari penelitian ini diketahui bahwa dalam berbagai perlakuan struktur hepar tikus dan mencit menunjukkan respon yang berbeda-beda terhadap suatu zat.
\end{abstract}

Kata Kunci : Pengaruh zat, hepar, tikus putih (Rattus norvegicus), mencit (Mus musculus)

\begin{abstract}
ABSTRAK
Hepar merupakan bagian organ yang memiliki fungsi yang sangat berguna bagi tubuh yang mana hepar berfungsi untuk menetralkan racun.Penyebab kerusakan sel-sel hepar antara lain oleh obat, virus dan berbagai macam senyawa lainnya yang mengandung hepatotoksik. Akan tetapi beberapa zat atau ekstrak mempunyai daya yang bisa menyembuhkan kerusakan sel hepar. Penelitian ini bertujuan untuk mengidentifikasi pengaruh pemberian beberapa zat terhadap perubahan struktur hepar tikus putih dan mencit. Metode penelitian menggunakan jenis penelitian studi pustaka yaitu kegiatan melakukan penelitian dengan cara membaca serta mempelajari literatur yang ada hubungannya dengan objek penelitian. Dari penelitian ini diketahui bahwa dalam berbagai perlakuan struktur hepar tikus dan mencit menunjukkan respon yang berbeda-beda terhadap suatu zat.
\end{abstract}

Kata Kunci : Pengaruh zat, hepar, tikus putih (Rattus norvegicus), mencit (Mus musculus) 


\section{PENDAHULUAN}

Banyaknya hewan tikus putih dan mencit yang ada disekitar bahkan ada beberapa masyarakat yang memelihara kedua tikus ini. Dari luar kedua hewan ini memiliki ukuran tubuh yang kecil dan memiliki ekor yang panjang. Banyaknya kesamaan dari kedua tikus ini membuat masyarakat susah membedakan terutama pada bagian organ penyusunnya yang didalamnya termasuk hepar.

Hepar merupakan bagian organ yang memiliki fungsi yang sangat berguna bagi tubuh yang mana hepar berfungsi untuk menetralkan racun. Racun yang masuk pada tubuh akan diproses oleh hepar untuk kemudian diubah menjadi zat tidak beracun. Dari proses ini maka akan menimbulkan sebuah gangguan pada hepar yaitu terjadi beberapa kerusakan (Aisyah, 2015).

Hepar dalam tubuh berada dibawah lambung yang mana hepar ini dalam menjalankan fungsinya yaitu dengan melakukan pemecahan senyawa berbahaya menjadi partikel yang lebih kecil (Sudatri et al., 2016). Hepar akan memiliki gangguan beberapa struktur selnya karena efek detoksifikasi oleh sebab itu akan terjadi keterbatasan fungsi dari organ ini yang disebabkan adanya zat berlebih yaitu zat toksik (Arfatul Makiyah, Sumirat Tresnayanti, 2017).

Sel-sel hati mampu berregenerasi dengan cepat itulah yang membuat hati tetap mampu menjalankan fungsinya meskipun terjadi beberapa ganggun kecil akan tetapi bisa berubah menjadi bahaya jika terjadi kerusakan yang parah (Martina Restuati, Poppy Audina Nasution, 2019). Hati merupakan salah satu kelenjar pencernaan yang memiliki peranan penting untuk membentuk dan mensekresikan empedu. Hati terletak pada kuadran kanan bagian atas rongga perut, permukaan atasnya membulat disesuaikan dengan kanopi diafragma (Ozougwu, 2017).

Berdasarkan kajian pustaka yang telah didapatkan, maka tujuan dari pembuatan artikel ini ialah untuk mengidentifikasi pengaruh pemberian beberapa zat terhadap perubahan struktur hepar tikus putih (Rattus norvegicus) dan mencit (Mus musculus).

\section{METODE}

Metode yang digunakan dalam pembuatan artikel ini adalah studi pustaka. Menurut M. Nazirr (1988) studi kepustakaan ialah teknik mengumpulkan data yang mengarahkan untuk mengkaji buku, literatur, catatan serta laporan yang mempunyai hubungan dengan masalah yang dipecahkan. Studi pustaka ialah kegiatan melakukan penelitian dengan cara membaca serta mempelajari literatur yang ada hubungannya dengan objek penelitian. Artikel ini mengambil sumber dari berbagai jurnal penelitian, sumber yang diambil terdapat sepuluh jurnal penelitian yang berkaitan dengan struktur histologis hepar tikus putih dan mencit. Kemudian data yang diperoleh akan dianalisis dan disimpulkan sehingga tujuan penelitian ini tercapai.

\section{PEMBAHASAN}

\section{Struktur sel hepar}

Sel-sel hepar memiliki sel berupa hepatosit dan sel makrofag. Sel hepatosit berperan penting dalam proses pertukaran zat atau proses metabolisme. Sel hepatosit bentuknya bulat dengan membentuk lapisan 1 sampai 2 sel terlihat susunannya seperti bata yang tersusun radier pada lobulus hepar. Lapisan sel ini dari tepian lobulus menuju ke pusat dan membentuk sebuah struktur menyerupai labirin dengan busa yang terbentuk dari proses anastomosis. Didalam hepar juga terdapat sinusoid hepar yang mana kapiler ini berada diantara lempeng. Senyawa pada hepar akan mengalami pertukaran zat yang akan menyebabkan berubahnya struktur dari segi kimia yang dirangsang oleh suatu enzim yang didapat pada mikrosom sel hepatosit atau biasa disebut biotransformasi. Pembuluh darah yang berada ditengah lobulus disebut vena sentralis

Berdasarkan penelitian dari Annisa Agata dkk (2016) menyatakan bahwa pada preparat hepatosit jika diberi pewarnaan hematoksilin-eosin maka akan terlihat 
didalam hepatosit terdapat inti sel dan sitoplasma yang mana inti sel terlihat berwarna biru dengan bentuk yang bulat. Sel hepatosit pada hepar mampu untuk menggandakan diri yang mana ini akan mempengaruhi sel lainnya untuk memecah menjadi bermacam sel yang beda. Sel yang terbentuk itu akan membentuk sebuah lobulus hepar yang baru.

\section{Eksperimen terhadap struktur sel hepar tikus putih}

Berdasarkan penelitian dari Noni Zakiah dkk (2017) menyatakan bahwa kerusakan struktur histologis pada hepar tikus putih dapat dicegah dengan memberikan ekstrak etanol daun sirsak, hal ini diakibatkan karena daun sirsak mengandung senyawa asetogenim sebagai antioksidan. Selain itu dalam artikel ini menyatakan bahwa antioksidan yang akan berperan dalam menangkap radikal bebas sehingga mencegah kerusakan sel hati yang telah terinduksi oleh parasetamol dosis tinggi. Oleh karena itu pemberian ekstrak etanol daun sirsak dapat melindungi dan mencegah kerusakan sel hati pada tikus putih.

Berdasarkan penelitian dari Arfatul Makiyah dan Lela Laelatul Khumaisah (2018) menyatakan bahwa pemberian ekstrak etanol umbi iles-iles pada struktur histologi hepar mencit dan tikus putih mengalami perbedaan. Pada struktur histologi hepar mencit mengalami kerusakan yaitu radang ringan hingga berat, sedangkan pada hepar tikus putih tidak mengalami kerusakan serta mampu mencegah kerusakan sel hati yang telah terinduksi oleh aspirin dengan dosis 150 $\mathrm{mm} / \mathrm{kgBB}$.

Berdasarkan penelitian dari Agung Putra Nugraha dkk (2018) menyatakan bahwa hepar yang mengalami gangguan atau kerusakan akan mampu diperbaiki oleh teh kombucha yang tentunya ini dikarenakan teh kombucha memiliki kemampuan untuk menghasilkan sebuah zat atau senyawa yang mampu menghalangi terjadinya kerusakan pada bagian selular hepar. Teh kombucha memiliki pengaruh terhadap perubahan pada hepar mencit dari segi struktur secara histologi berupa degenerasi parenkimatosa, degenerasi hidropik dan nekrosis.

Berdasarkan penelitian dari Noer Kumala Indahsari (2017) menyatakan bahwa secara makroskopis, sel hepatosit memiliki inti bulat, sitoplasma yang jernih dengan susunan yang teratur membentuk lempengan radier yang mengarah ke vena sentralis. Apabila sel hepar terinduksi parasetamol dengan dosis taksik maka akan menimbulkan kerusakan pada sel hepar. Akibatnya terjadi tahapan stress oksidatif, yang mana adanya tumpukan metabolit NAPQ1 yang menimbulkan kerusakan pada mitokondria dan menjadi penghambat bagi sel hepatosil dalam membentuk energi. Adapun ciri dari cedera yang terjadi pada sel hepar akibat parasetamol yaitu penurunan jumlah protein total maupun glikogen. Hal ini disebabkan oleh berkurangnya produksi protein dan glikogen oleh sel hepatosit, sehingga berat organ hati berkurang dari ukuran normalnya. Timbulnya cloudy swelling yang menandakan awal munculnya gejala nekrosis pada sel hati.

\section{Eksperimen terhadap struktur sel hepar mencit}

Berdasarkan penelitian dari Ni Komang Tia Pramesti dkk (2017) menyatakan bahwa struktur histologis hati mencit setelah diberikan ekstrak daun ekor naga tidak menyebabkan kerusakan sel-sel hati mencit namun menyebabkan kerusakan pada system peredaran darah mencit. Hal ini diakibatkan karena sel-sel hati dapat 
melakukan proses regenerasi sel yaitu dapat memperbaiki sel yang rusak dengan mengganti dengan sel yang baru.

Berdasarkan penelitian dari Reza Anindita dkk (2012) menyatakan bahwa struktur histologi hepar mencit dapat mengalami kerusakan akibat monosodium glutamat (MSG), namun dengan pemberian teh hijau dapat memperbaiki kerusakan hepar mencit tersebut. Hal ini disebabkan karena didalam teh hijau mengandung flavonoid yang berperan dalam membersihkan radikal bebas.

Berdasarkan penelitian dari Dwi Indah Latifah Ningrum dkk (201) menyatakan bahwa struktur histologi hati mencit setelah diberikan ekstra ikan gabus tidak mengalami kerusakan, dan ekstra tersebut membantu dalam memperbaiki kerusakan sel-sel hati pada mencit. Ekstra ikan gabus mengandung antioksidan berupa albumin sehingga dapat membuat radikan bebas menjadi molekul, hal inilah yang menyebabkan ekstra ikan gabus dapat memperbaiki kerusakan pada sel-sel hati mencit.

\section{KESIMPULAN}

Hasil studi literatur yang telah dilakukan menunjukkan bahwa adanya perubahan struktur hepar tikus putih dan mencit terhadap pemberian beberapa zat. Zat yg bersifat hepatotoksik dapat menyebabkan kerusakan, sedangkan ada zat yang juga dapat memperbaiki kondisi hepar tikus dan mencit yang rusak.

\section{DAFTAR PUSTAKA}

Agata, Annisa dkk. (2016). Respon Histopatologis Hepar Mencit (Mus musculus) yang Diinduksi Benzo( $\alpha)$ Piren terhadap Pemberian Taurin dan Ekstrak Daun Sirsak (Annona muricata). Jurnal Natur
Indonesia Jurnal Natur Indonesia 16(2), April 2016: 54 16(2): 54-63 -

63.

Aisyah, S., H. Budiman., D. Florenstina., dan D. Aliza. (2015). Efek pemberian Minyak Jelantah terhadap Gambaran Histopatologis Hati TikusPutih. Jurnal Media Veterinaria. 9(1) : 23.

Anindita, Reza. (2012). Potensi Teh Hijau (Camelia sinensis L.) Dalam Perbaikan Fungsi Hepar Pada Mencit Yang Diinduksi Monosodium Glutamat (MSG). Buletin Anatomi dan Fisiologi Volume XX, Nomor 2, Oktober 2012.

Ermayanti, Ni Gusti Ayu Manik. (2014). Struktur Histologi Hati Mencit (Mus musculus L.) Setelah Perlakuan Monosodium Glutamat (MSG). Prosiding Seminar Nasional Prodi Biologi F. MIPA UNHI. Denpasar: Universitas Hindu Indonesia.

Indahsari, Noer Kumala. (2017). Histopatologi Hepar Tikus Putih (Rattus novergicus) Yang Diinduksi Dengan Parasetamol Dosis Toksik Pasca Pemberian Ekstrak Etanol Daun Kelor (Moringa oleifera). Jurnal Kimia Riset, Volume 2 No. 2, Desember 2017.

Makiyah, Arfatul dan Lela Laelatul Khumaisah. (2018). Studi Gambaran Histopatologi Hepar Tikus Putih Strain Wistar yang Diinduksi Aspirin Pascapemberian Ekstrak Etanol Umbi Iles-iles (Amorphophallus variabilis Bl.) Selama 7 Hari. Majalah Kedokteran Bandung, Volume 50 No. 2, Juni 2018. Sukabumi: Universitas Muhammadiyah Sukabumi.

Nazir, Mohammad. (1988). Metodologi Penelitian. Jakarta: Ghalia Indonesia.

Ningrum, Dwi Indah Latifah dan Dra. Nurlita Abdulgani. (2014). Pengaruh Pemberian Ekstrak Ikan Gabus (Channa striata) pada Struktur Histologi Hati Mencit (Mus musculus) Hiperglikemik. Jurnal Sains Dan Seni Pomits Vol. 2, No.1, (2014) 2337- 
3520 (2301-928X Print).

Nugraha, Agung Putra. (2018). Histopatologi Hepar Tikus Wistar (Rattus norvegicus) Jantan setelah Pemberian The Kombucha Konsentrasi $100 \%$ dengan Waktu Fermentasi yang Berbeda. Buletin Anatomi dan Fisiologi Volume 3 Nomor 1 Februari 2018.

Ozougwu J. (2017). Physiology of the Liver. International Journal of Research in Pharmacy and Biosciences. 4(8): 13-24.

Pramesti, Ni Komang Tia. (2017). Struktur Histologi Hati Mencit(Mus musculus L.) Setelah Pemberian Ekstrak Daun Ekor Naga (Rhapidhophora pinnata Schott). Jurnal Simbiosis V (2 ): 43-46 ISSN: 2337-7224 Jurusan Biologi FMIPA Universitas Udayana.

Restuati, Martina dan Poppy Audina Nasution. (2019). Pengaruh Ekstrak Etanol Daun Buas buas (Premna Pubescens Blume) Terhadap Gambaran Histopatologi Hati Pada Tikus putih (Rattus Novergicus) Yang Diinduksi Kanker 7,12 Dimethylbenz.

[a] antrasena (DMBA). Jurnal Biosains. 5 (2): 77

Sudatri, I.W., I. Setyawati., N.M Suartini dan D.A Yulihastuti. (2016). Penurunan Fungsi Hati Tikus Betina (Rattus Norvegivus L) Yang Diinjeksi White Vitamin C Dosis Tinggi Dalam Jangka Waktu Lama Ditinjau Dari Kadar SGPT, SGOT Serta Gambaran Histologi Hati. Jurnal Metamorfosis. 3 (1): 44-51.

Sugihartini, Nining dan M. Alif Fajri. (2016). Gambaran Histopatologi Organ Hati dan Ginjal Mencit Balb/c setelah Pemberian Krim Ekstrak Teh Hijau (Camellia sinensis L.). Jurnal Farmasi dan Ilmu Kefarmasian Indonesia Vol. 3 No. 1 Juli 2016.
Zakiah, Noni dkk. (2017). Aktifitas Hepatoprotektif Ekstrak Etanol Daun Sirsak (Annona muricata L.) Terhadap Kerusakan Hati Tikus Yang Diinduksi Dengan Parasetamol. Jurnal AcTion: Aceh Nutrition Journal, Mei 2017; 2(1): $25-3$ 